\title{
Operando Near Ambient Pressure XPS (NAP-XPS) Study of the Pt Electrochemical Oxidation in $\mathrm{H}_{2} \mathrm{O}$ and $\mathrm{H}_{2} \mathrm{O} / \mathrm{O}_{2}$ Ambients
}

Viktoriia A. Saveleva, ${ }^{\dagger}$ Vasiliki Papaefthimiou, ${ }^{\dagger}$ Maria K. Daletou, ${ }^{\ddagger}$ Won H. Doh, ${ }^{\dagger}{ }^{\perp}$ Corinne Ulhaq-Bouillet, ${ }^{\S}$ Morgane Diebold, ${ }^{\dagger}, \|$ Spyridon Zafeiratos, ${ }^{\dagger}$ Elena R. Savinova*,†

\author{
†Institut de Chimie et Procédés pour l'Energie, l'Environnement et la Santé, UMR 7515 du CNRS-UdS, 25 Rue \\ Becquerel, 67087 Strasbourg, France \\ ${ }^{\ddagger}$ Foundation of Research and Technology Hellas, Institute of Chemical Engineering Sciences, FORTH/ICE-HT, Stadiou \\ Str., Platani Rion, Patras 26504, Greece \\ §Institut de Physique et Chimie des Matériaux de Strasbourg, 23 rue du Loess, BP 43, 67037, Strasbourg, France
}

\section{Supporting Information}




\section{X-ray difractogramm of Pt nanoparticles}

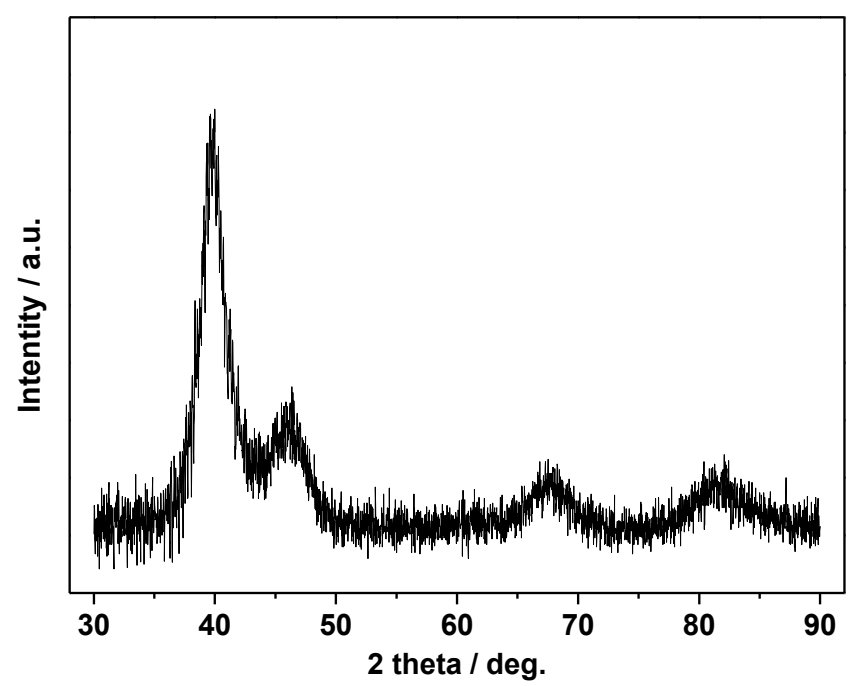

Figure S1: X-ray diffraction pattern of unsupported Pt nanoparticles (powder). 
SEM image of the Pt working electrode

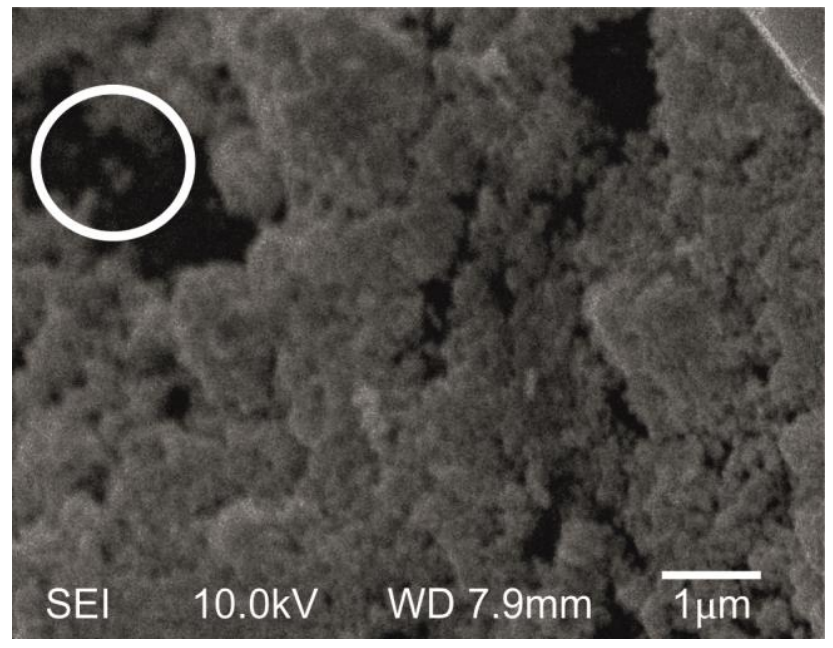

Figure S2: SEM image of the Pt working electrode.

Disconnected particles are marked with a white circle. 


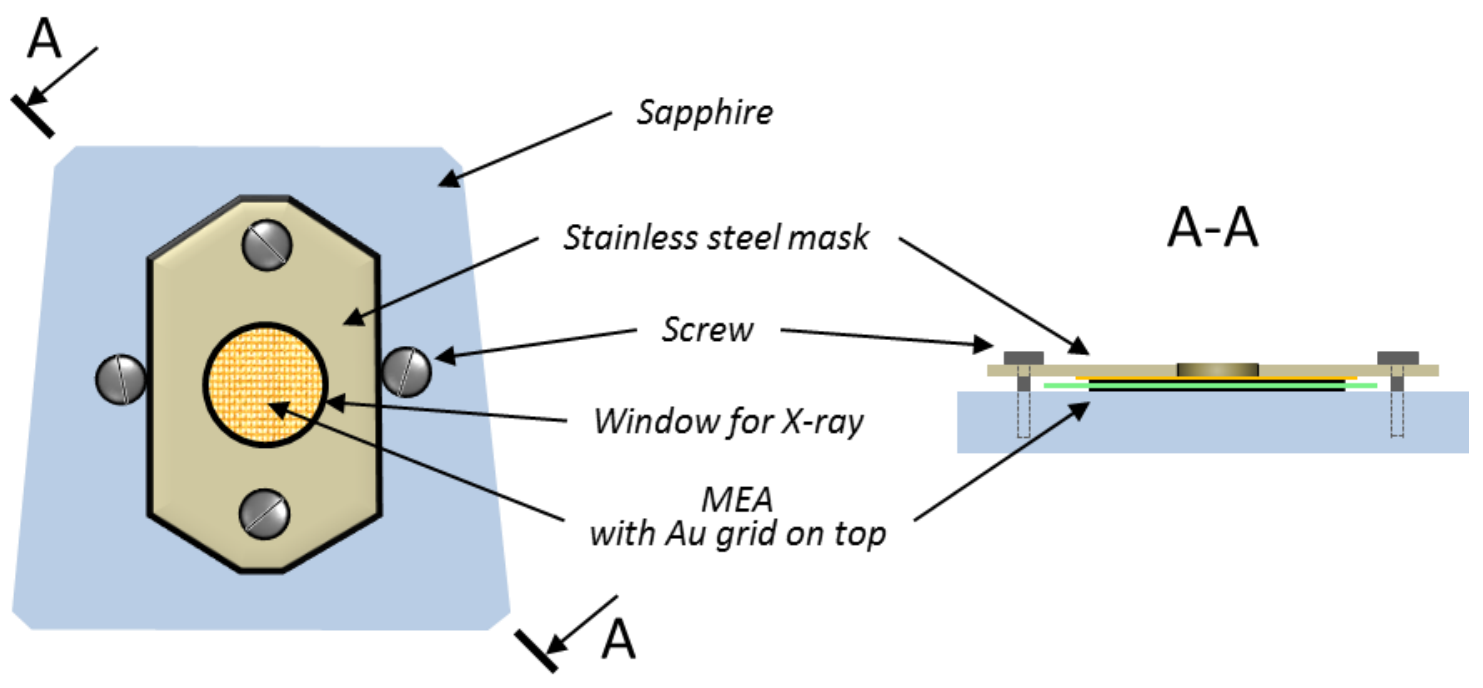

Figure S3: Sketch of the holder used to fix the MEA in the NAP-XPS chamber. 


\section{Calibration of the potential scale vs. the dynamic hydrogen electrode}

To define the potential of the working electrode on the hydrogen electrode scale a $\mathrm{CV}$ of the WE was measured in the presence of hydrogen in the NAP-XP chamber (panel A of Figure S4) right before the start of the spectroscopic measurements. In this case the polarization at the counter electrode is negligibly small and it may be used as a dynamic hydrogen electrode (DHE). Comparison of the CVs measured in water/hydrogen and in water ambient shows that the latter is shifted negative by ca. $0.93 \mathrm{~V}$ compared to the former. This allows us to estimate the OCV attained in the NAP-XP chamber in the presence of 0.1 mbar water vapor as $0.93 \mathrm{~V}$ vs. DHE. Note that addition of hydrogen in the NAP-XPS chamber not only induces a positive shift of the CV along the potential axis, but also results in a positive shift along the current axes. The latter is due to the fact that in our experimental set-up the counter and the working electrode are exposed to the same environment (see Figure S3), and thus, when hydrogen is introduced in the NAPXPS chamber, it can react both at the working and at the counter electrode. The interaction of hydrogen with the surface of the Pt working electrode may influence its coverage with oxygen species. Note that in our previous publication ${ }^{1}$ we noticed an influence of hydrogen on the surface state of a bimetallic AuPt electrode. To avoid influence of hydrogen on the state of the Pt surface we did not introduce it into the NAPXPS chamber during the spectra acquisition. 

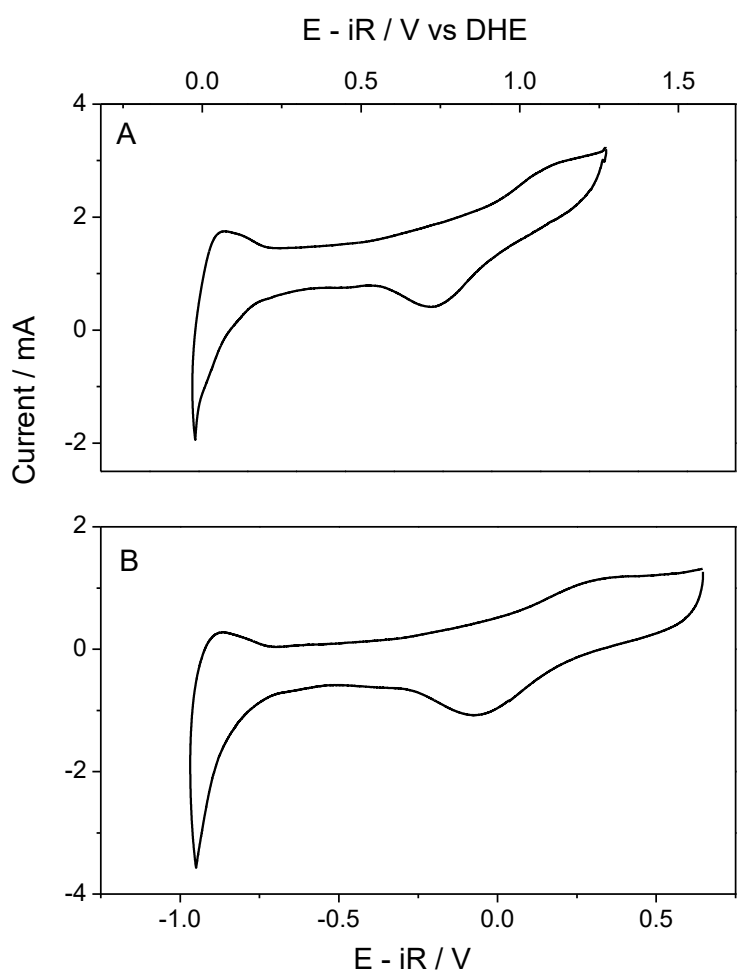

Figure S4: Cyclic voltammograms recorded in the chamber of the NAP-XP spectrometer at $150^{\circ} \mathrm{C}$ at 0.2 mbar in $\mathrm{H}_{2} \mathrm{O}: \mathrm{H}_{2}=1: 1$ mixture $(A)$ and $0.1 \mathrm{mbar}^{\mathrm{H}} \mathrm{H}_{2} \mathrm{O}(\mathrm{B})$ at a sweep rate of $100 \mathrm{mV} \mathrm{s}^{-1}$. 


\section{Cyclic voltammetry - influence of $\mathrm{O}_{2}$}

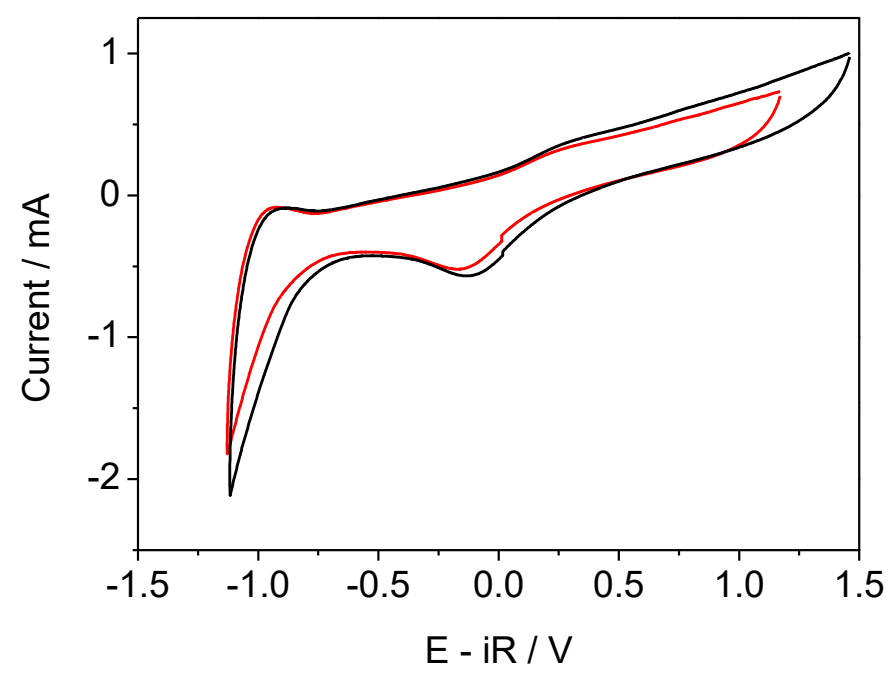

Figure S5: Cyclic voltammograms recorded in the chamber of the NAP-XP spectrometer at $150^{\circ} \mathrm{C}$ in $0.1 \mathrm{mbar}_{2} \mathrm{O}$ (black curve) and $0.11 \mathrm{mbar}_{2} \mathrm{O} / 0.16$ mbar $\mathrm{O}_{2}$ (red curve) at a sweep rate of $50 \mathrm{mV} \mathrm{s}^{-1}$. Note that introducing $\mathrm{O}_{2}$ in the NAP-XPS chamber results only in a small shift of the $\mathrm{CV}$ along the potential axis suggesting close values of the OCV in the presence and in the absence of oxygen. This may be attributed to the low partial pressure of $\mathrm{O}_{2}$ and slow kinetics of the oxygen reactions resulting in establishing a mixed rather than an equilibrium potential at the WE. The inclination of the CVs may be tentatively attributed to the non-uniform distribution of the pressure in the MEA (see Figure S3). Indeed, the stainless-steel cover used to fix the sample on the holder exerts stronger pressure on the periphery of the MEA compared to its center. This may lead to a different distribution of the phosphoric acid electrolyte between the sample's periphery and its center. Note that while the CV corresponds to the WE as a whole, the XP spectra are only collected from the central part of the MEA, which is not affected by the inhomogeneities in the electrolyte distribution. The stronger inclination of the CVs of Figure S5 compared to those shown in Figure 2 and Figure S4 is due to the lower sweep rate in the former. 


\section{Estimation of the Pt utilization under the measurement conditions}

To roughly estimate the electrochemically active surface area (ECSA) of Pt under the experimental conditions we integrated the charge of the $\mathrm{CV}$ presented in figure $\mathrm{S} 4 \mathrm{~B}$, and normalized it to $0.420 \mathrm{mC} \mathrm{cm}^{-2}$, assuming a full monolayer of adsorbed oxygen. This gave an estimated ECSA of $16.5 \mathrm{~cm}^{2}$. To estimate the degree of Pt utilization we estimated the total surface area of Pt nanoparticles by considering the Pt loading (ca 0.08 $\left.\mathrm{mg} \mathrm{cm}{ }^{-2}\right)$, the WE surface area $\left(0.25 \mathrm{~cm}^{2}\right)$, and the average size of Pt crystallites of $4 \mathrm{~nm}$ (based on the XRD data). Assuming a spherical particle shape the total surface area of Pt was estimated as ca. $14 \mathrm{~cm}^{2}$. Comparable values of the "theoretical" surface area of the Pt particles and the ECSA suggest that the extent of Pt utilization in this work is high and might approach $100 \%$. Note that our estimate is very rough because of the overestimation of the ECSA (we know from XPS data that at considered potentials more than a monolayer of the Pt surface oxide may be formed). Also, there is some uncertainty in the Pt loading on the MEA, and in the estimation of the "theoretical" surface area of pt particles. Nevertheless, one may conclude that the degree of Pt utilization in our experiments is high. This may be attributed to the utilization of a thin layer of unsupported Pt nanoparticles in this work. Note that the Pt utilization in commercial MEAs of HT PEMFCs with Pt/C electrodes is above $60 \%$.

The high Pt utilization makes us confident that nearly all Pt particles are polarized. As mentioned in the manuscript, a small fraction of Pt particles is not polarized (disconnected Pt particles encircled in Fig. S5), and this is manifested by a separate polarizationdependent peak in the Pt4f spectra (Fig. 3). 


\section{Stability of the electrolyte}

In Figure S3, the $\mathrm{O} / \mathrm{P}$ atomic ratios are plotted as a function of the applied voltage in water and water/oxygen atmospheres. The $\mathrm{O} / \mathrm{P}$ atomic ratios was equal to 3.5 for the 0.1 mbar $\mathrm{H}_{2} \mathrm{O}$ and 4 for the $0.27 \mathrm{mbar}_{2} \mathrm{O}: \mathrm{O}_{2}$ ambient. The theoretical values for different chemical states of the electrolyte are 4 (for ortho-phosphoric acid $\mathrm{H}_{3} \mathrm{PO}_{4}$ ) and 3.5 (for pyro-phosphoric acid $\mathrm{H}_{4} \mathrm{P}_{2} \mathrm{O}_{7}$ ). The experimentally obtained values suggest that the electrolyte is likely to be dominated by the ortho-phosphoric acid, although the experimental error does not allow making an unambiguous conclusion. Stability of the $\mathrm{O} / \mathrm{P}$ ARs in both atmospheres suggests that the electrolyte does not dry out under the experimental conditions employed.

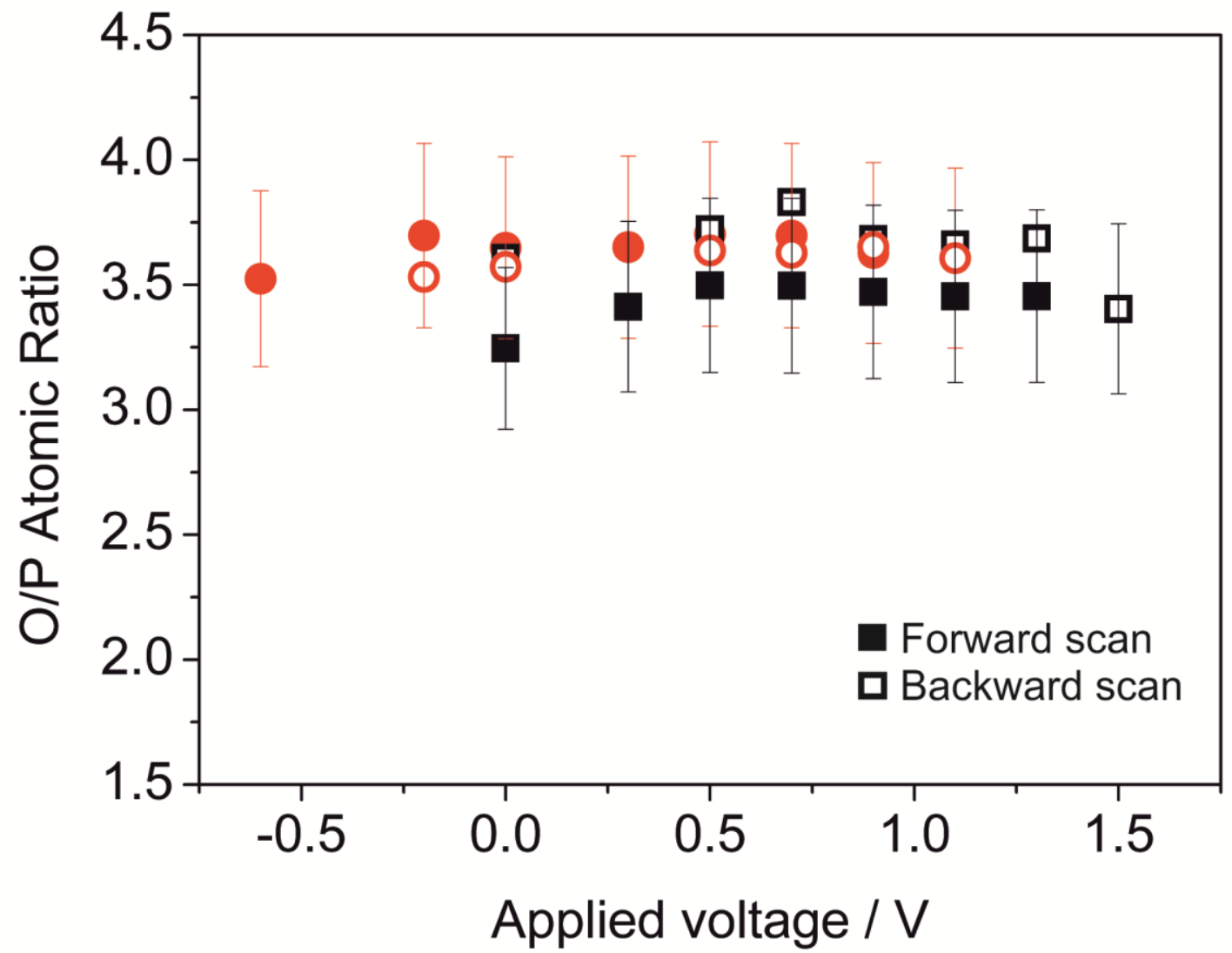

Figure S6: $\mathrm{O} / \mathrm{P}$ atomic ratios measured under polarization in 0.1 mbar $\mathrm{H}_{2} \mathrm{O}$ (black symbols) and 0.11 mbar $\mathrm{H}_{2} \mathrm{O} / 0.16$ mbar $\mathrm{O}_{2}$ (red symbols) versus the applied voltage. Filled symbols correspond to the forward, while open symbols - to the backward voltage scan. 


\section{Influence of the interface polarization on the BE shifts}

The main proof of the proper operation of the MEA under the near-ambient pressure conditions is the evidence of the polarization of the interface between Pt particles and the electrolyte. In figure S7, the evolution of the XP peaks corresponding to the species originating from the $\mathrm{WE}(\mathrm{Pt})$, electrolyte $(\mathrm{P}, \mathrm{O})$ and hydrocarbon membrane $(\mathrm{C})$ are shown, at selected values of the applied voltage bias between the WE and the CE. The BEs of the elements related to the electrolyte $(\mathrm{O} 1 \mathrm{~s}, \mathrm{P} 2 \mathrm{p})$ and the HT membrane $(\mathrm{C} 1 \mathrm{~s})$ shift with the applied voltage, confirming polarization of the interface (Figure S7 A-C). On the contrary, the position of the main Pt4f peak (which corresponds to metallic $\mathrm{Pt}$ ) remains constant (Figure S7D), since the WE is grounded to the spectrometer trough the Au grid. All BE shifts are plotted as a function of the cell voltage for each element (bottom graph, Figure S7). The slope of the curves is equal to 1 with an error margin $\pm 0.15 \mathrm{eV}$, confirming that the interface is indeed polarized.

As mentioned in the main text, the Pt 4f XP spectra were deconvoluted in 5 doublets, one corresponding to metallic Pt, three to Pt surface oxides/hydroxides, and one referred to as "disconnected" Pt (see SEM image in Figure S5). The BE shifts of the latter with the applied voltage follow those of $\mathrm{O} 1 \mathrm{~s}, \mathrm{P} 2 \mathrm{p}$, and $\mathrm{C} 1 \mathrm{~s}$, as evident from the bottom graph of Fig. S7. Therefore, one can consider that these Pt species correspond to separated nanoparticles or agglomerates, which are not in contact with the current collector. Similar "disconnected" Au components have been already observed in our previous studies. ${ }^{1}$ Note that this disconnected Pt component was not taken into account during the calculations of the atomic fractions of metallic and oxidized Pt components (e.g. Figure 4, main text). 

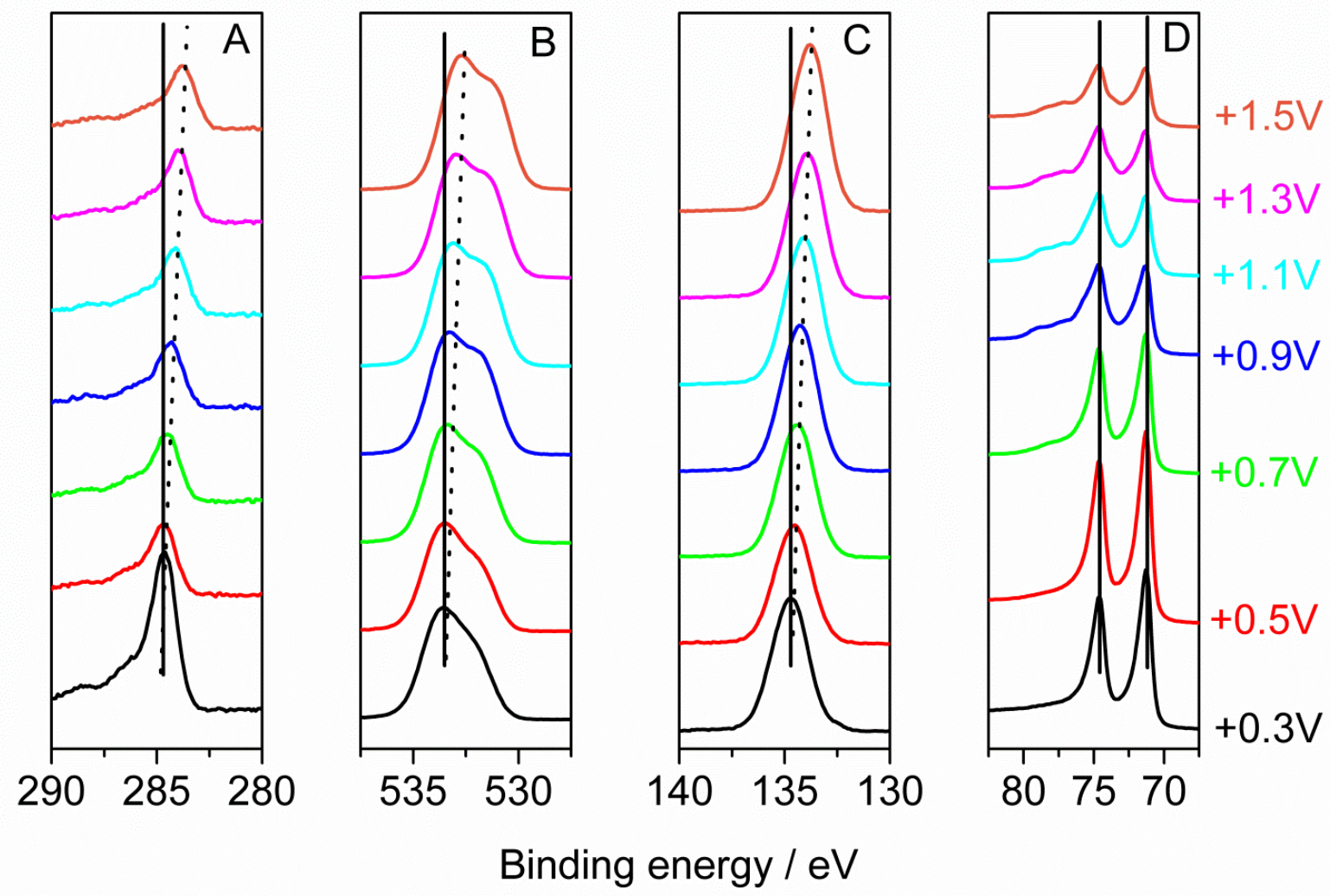

Binding energy / eV

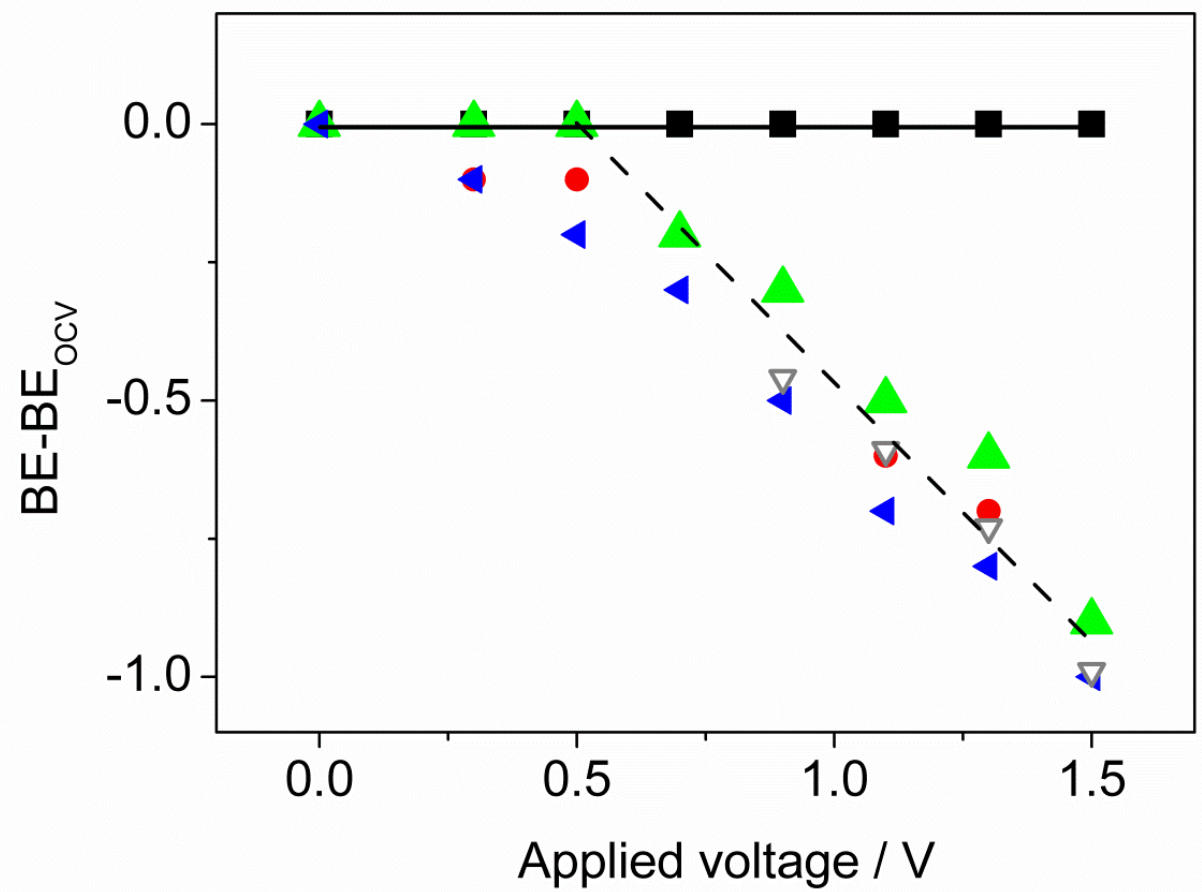

Figure S7: Top panel: C1s (A), O1s (B), P2p (C) and Pt4f (D) spectra at various cell voltages under 0.1 mbar $\mathrm{H}_{2} \mathrm{O}$ and $150{ }^{\circ} \mathrm{C}$. Bottom panel: The BEs of the $\mathrm{Pt}_{4} \mathrm{f}_{7 / 2}$ main peak (black), O1s (green), C1s (red), P2p (blue), $\mathrm{Pt}_{4 \mathrm{f}_{7 / 2}}$ "disconnected" (gray) peaks as a function of the applied voltage are given in the bottom graph. 
Table S1: Literature values of the binding energy (BE) for metallic and oxidized Pt*

\begin{tabular}{|c|c|c|c|c|c|c|}
\hline \multicolumn{4}{|c|}{$\begin{array}{c}\text { BE of } \mathrm{Pt} 4 \mathrm{f}_{7 / 2}\left(\mathrm{BE}-\mathrm{BE}_{\mathrm{met}}\right) \\
\mathrm{eV}\end{array}$} & \multirow{2}{*}{ Sample description } & \multirow{2}{*}{ Conditions } & \multirow{2}{*}{ Ref } \\
\hline $\mathrm{Pt}^{0}$ & $\mathrm{PtO}$ & $\mathrm{PtO}_{2}$ & $\begin{array}{l}\text { Chemi- } \\
\text { sorbed O }\end{array}$ & & & \\
\hline \multicolumn{7}{|c|}{ Bulk-like Pt in single crystals, polycrystalline samples and films } \\
\hline 70.7 & $\begin{array}{l}73.3 \\
(+2.6)\end{array}$ & $74.1(+3.4)$ & $\begin{array}{l}71.6 \\
(+0.9)\end{array}$ & Polycrystalline Pt foil & $\begin{array}{l}0 \div 2.2 \mathrm{~V} \text { vs. } \mathrm{RHE} \text { in } 1 \mathrm{M} \mathrm{HClO}_{4} \\
\text { at } \mathrm{RT}\end{array}$ & 2 \\
\hline 71.3 & $\begin{array}{l}72.4 \\
(+1.1)\end{array}$ & $74.2(+2.9)$ & & Thick Pt film $/ \mathrm{Al}_{2} \mathrm{O}_{3}$ & Oxidation in $\mathrm{Ar} / \mathrm{O}_{2}$ atmosphere & 3 \\
\hline 71.0 & $\begin{array}{l}72.2 \\
(+1.2)\end{array}$ & $74.0(+3.0)$ & & $\begin{array}{l}\text { Polycrystalline thin Pt foil } \\
\text { (commercial sample) }\end{array}$ & RT & 4 \\
\hline 71.2 & $\begin{array}{l}72.7 \\
(+1.5)\end{array}$ & $74.1(+2.9)$ & & Pt film/ $/ \mathrm{TiO}_{2}(110)$ & $\begin{array}{l}300 \mathrm{~K} \\
\text { Air atmosphere }\end{array}$ & 5 \\
\hline 70.5 & & & $\begin{array}{l}71.1-71.3 \\
(+0.6- \\
0.8)\end{array}$ & $\operatorname{Pt}(111)$ & $\begin{array}{l}25 \mathrm{~K}-200 \mathrm{~K} \\
\text { Different oxygen dosing }\end{array}$ & 6 \\
\hline 71.1 & $\begin{array}{l}72.2 \\
(+1.1)\end{array}$ & & & $\begin{array}{l}\mathrm{Pt} \text { film }(250-500 \mathrm{~nm}) / \\
\mathrm{Si}(100)\end{array}$ & $\begin{array}{l}30-700^{\circ} \mathrm{C} \\
\mathrm{O}_{2} / \text { Ar atmosphere }\end{array}$ & 7 \\
\hline 71.2 & $\begin{array}{l}73.5 \\
(+2.3)\end{array}$ & & & $\operatorname{Pt}(111)$ & $\begin{array}{l}\text { Reaction with atomic oxygen } \\
\text { RT }\end{array}$ & 8 \\
\hline 71.2 & $\begin{array}{l}72.5 \\
(+1.3)\end{array}$ & $73.9(+2.7)$ & & $\begin{array}{l}\mathrm{Pt} \text { film }(130 \mathrm{~nm}) / \mathrm{TiO}_{\mathrm{x}}(50 \\
\mathrm{nm}) / \mathrm{SiO}_{2}\end{array}$ & Oxygen plasma (5mTorr) & 9 \\
\hline 71.2 & $\begin{array}{l}72.3 \\
(+1.1)\end{array}$ & $74.1(+2.9)$ & & $\mathrm{Pt}$ film $(2.5-13 \mathrm{~nm}) / \mathrm{SiO}_{2} / \mathrm{Si}$ & $\begin{array}{l}\text { Oxygen plasma (100mTorr; } \\
100 \mathrm{~W})\end{array}$ & 10 \\
\hline 71 & $\begin{array}{l}72.5 \\
(+1.5)\end{array}$ & $74.5(+3.5)$ & $\begin{array}{l}71.6 \\
(+0.6)\end{array}$ & Pt NPs film/Nafion (MEA) & $\begin{array}{l}\text { NAP-XPS } \\
\text { Cell voltage } 2 \text { and } 2.5 \mathrm{~V} \text { in } \\
\text { water vapor at RT }\end{array}$ & 11 \\
\hline 71.2 & $\begin{array}{l}72.6 \\
(+1.4)\end{array}$ & $74.1(+2.9)$ & & Polycrystalline Pt foil & $\begin{array}{l}\text { NAP-XPS, "dip\&pull" method } \\
2 \text { and } 2.5 \mathrm{~V} \text { vs SCE in } 16-20 \\
\text { Torr } \mathrm{H}_{2} \mathrm{O} \text { at RT }\end{array}$ & 12 \\
\hline 71.0 & $\begin{array}{l}73.6 \\
(+2.6)\end{array}$ & $74.4(+3.4)$ & & Polycrystalline Pt electrode & $\begin{array}{l}0 \div 2.2 \text { vs. } \mathrm{SCE} \text { in } \mathrm{HClO}_{4} \\
\mathrm{H}_{2} \mathrm{SO}_{4} \text { at RT }\end{array}$ & 13 \\
\hline 71.2 & $72.2(+1)$ & $74.2(+2)$ & & Polycrystalline Pt rod & $\begin{array}{l}0 \div 1.5 \text { V vs. } \mathrm{SCE} \text { in } 0.5 \mathrm{M} \\
\mathrm{H}_{2} \mathrm{SO}_{4} \text { at RT }\end{array}$ & 14 \\
\hline \multirow{3}{*}{71.3} & & $\begin{array}{l}78.3-78.5 \\
(+3.65- \\
3.85)\end{array}$ & & $\begin{array}{l}\mathrm{PtO}_{2} \bullet \mathrm{H}_{2} \mathrm{O} \\
(\text { commercial })\end{array}$ & & \multirow[t]{3}{*}{15} \\
\hline & & $\begin{array}{l}77.8 \\
(+3.15)\end{array}$ & & $\begin{array}{l}\mathrm{PtO}_{2} \bullet \mathrm{H}_{2} \mathrm{O} \quad \text { chemically } \\
\text { formed on } \mathrm{Pt}\end{array}$ & $400{ }^{\circ} \mathrm{C}$ in fused $\mathrm{NaNO}_{3}$ & \\
\hline & $\begin{array}{l}73.8 \\
(+2.5)\end{array}$ & $74.6(+3.3)$ & & $\begin{array}{l}\mathrm{PtO}_{2} \bullet \mathrm{H}_{2} \mathrm{O} \\
\text { electrochemically formed } \\
\text { on } \mathrm{Pt}\end{array}$ & $\begin{array}{l}0 \div 1.3 \text { V vs. SCE in } 0.5 \mathrm{M} \\
\mathrm{H}_{2} \mathrm{SO}_{4} \text { at } \mathrm{RT}\end{array}$ & \\
\hline 71.8 & & & & $\begin{array}{l}\mathrm{Pt} \text { evaporated/ } \mathrm{CeO}_{2} \text { and } \\
\mathrm{SiO}_{2}\end{array}$ & RT & 16 \\
\hline 71.1 & & & & $\operatorname{Pt}(111)$ & RT & 17 \\
\hline \multicolumn{7}{|c|}{ Oxidized Pt nanoparticles } \\
\hline 71.3 & $\begin{array}{l}72.2 \\
(+0.9)\end{array}$ & $73.8(+2.5)$ & $\begin{array}{l}75.0 \\
(+3.7)\end{array}$ & $\begin{array}{l}\text { Nanostructured } \\
\text { electrode }(\mathrm{MEA})\end{array}$ & $\begin{array}{l}\mathrm{NAP}-\mathrm{XPS} \\
0 \div 0.9 \mathrm{~V} \text { vs. OCV in } 0.1 \mathrm{mbar} \\
\mathrm{H}_{2} \mathrm{O} \text { at } 150^{\circ} \mathrm{C}\end{array}$ & $\begin{array}{l}\text { This } \\
\text { work }\end{array}$ \\
\hline
\end{tabular}




\begin{tabular}{|c|c|c|c|c|c|c|}
\hline 71.5 & 74.4 & & & $\begin{array}{l}\mathrm{PtO}(\sim 2 \mathrm{~nm}) \text { powder } \\
(\text { commercial) }\end{array}$ & RT & 18 \\
\hline \multirow{3}{*}{71.0} & & & & Pt film (100nm) & \multirow{3}{*}{$\begin{array}{l}8 \text { and } 64 \mathrm{~h} \mathrm{O}_{2} \text { atmosphere } \\
(150 \text { Torr) at RT }\end{array}$} & \multirow[t]{3}{*}{19} \\
\hline & $\begin{array}{l}74.6 \\
(+3.6)\end{array}$ & & $\begin{array}{l}72.3-72.6 \\
(+1-1.3)\end{array}$ & Pt NPs $(<3.5 \mathrm{~nm}) /$ Teflon & & \\
\hline & $\begin{array}{l}75.2 \\
(+4.2)\end{array}$ & & $\begin{array}{l}73.3 \\
(+2.3)\end{array}$ & $\operatorname{Pt} \mathrm{NPs}(<3.5 \mathrm{~nm}) / \mathrm{SiO}_{2}$ & & \\
\hline 71.2 & $\begin{array}{l}72.3 \\
(+1.1)\end{array}$ & $73.6(+2.4)$ & & $\mathrm{Pt}(4 \mathrm{~nm}) / \mathrm{La}_{2} \mathrm{O}_{3}-\mathrm{ZrO}_{2}$ & $\begin{array}{l}\text { Oxygen }(6 \%) / \text { nitrogen } \\
\text { atmosphere at } 450^{\circ} \mathrm{C}\end{array}$ & 20 \\
\hline 71.55 & $\begin{array}{l}72.93 \\
(+1.38)\end{array}$ & $\begin{array}{l}74.5 \\
(+2.95)\end{array}$ & & $\mathrm{Pt}(30$ wt. $\%) / \mathrm{C}(3.5 \mathrm{~nm})$ & RT, fuel cell mode & 21 \\
\hline $\begin{array}{l}70.8- \\
71.0\end{array}$ & $\begin{array}{l}71.8-72.1 \\
(+1-1.1)\end{array}$ & & & $\mathrm{Pt}(1-2$ wt. $\%) / \mathrm{SiO}_{2}$ & & 22 \\
\hline 71 & $\begin{array}{l}71.9 \\
(+0.9)\end{array}$ & $74.2(+3.2)$ & & $\operatorname{Pt}(1$ at. $\%) / \mathrm{TiO}_{2}(6-7 \mathrm{~nm})$ & RT & 23 \\
\hline 71.5 & $\begin{array}{l}72.3 \\
(+0.8)\end{array}$ & $73.5(+2.0)$ & & $\mathrm{Pt} / \mathrm{ZrO}_{2}(13 \mathrm{~nm})$ & RT & 24 \\
\hline 71.1 & $\begin{array}{l}72.8 \\
(+1.7)\end{array}$ & $74.3(+3.2)$ & & $\begin{array}{l}\mathrm{Pt}(\sim 3 \mathrm{~nm}) / \text { multiwall } \mathrm{C} \\
\text { nanotubes }\end{array}$ & $\begin{array}{l}-0.2 \div 1.0 \mathrm{~V} \text { vs. SCE in } 0.5 \mathrm{M} \\
\mathrm{H}_{2} \mathrm{SO}_{4} \text { at RT }\end{array}$ & 25 \\
\hline 71.1 & $\begin{array}{l}72.4 \\
(+1.3)\end{array}$ & $74.2(+3.1)$ & & $\begin{array}{l}\mathrm{Pt}(5-10 \mathrm{~nm}) / \text { single wall } \mathrm{C} \\
\text { nanotubes }\end{array}$ & $\begin{array}{l}0.05 \mathrm{~V} \text { vs. RHE in } 0.5 \mathrm{M} \mathrm{H}_{2} \mathrm{SO}_{4} \\
\text { at RT }\end{array}$ & 26 \\
\hline $\begin{array}{l}71.2- \\
72.2\end{array}$ & & $\begin{array}{l}74.3-75.5 \\
(+3.1-3.3)\end{array}$ & & Pt NPs $(2-4 \mathrm{~nm}) / \mathrm{C}$ & $200-400^{\circ} \mathrm{C}$ & 27 \\
\hline 71.1 & $\begin{array}{l}72.3 \\
(+1.2)\end{array}$ & $73.8(+2.7)$ & & $\begin{array}{l}\text { Pt NPs }(3.6 \text { and } 6.6 \mathrm{~nm}) / \\
\mathrm{SiO}_{2}\end{array}$ & $\begin{array}{l}\text { Oxygen plasma }\left(4 \cdot 10^{-5} \mathrm{mbar} \text {, }\right. \\
120 \mathrm{~min}) \text { at RT }\end{array}$ & 17 \\
\hline
\end{tabular}

*If not otherwise stated, measurements were performed with ex situ XPS 


\section{Depth profiling}
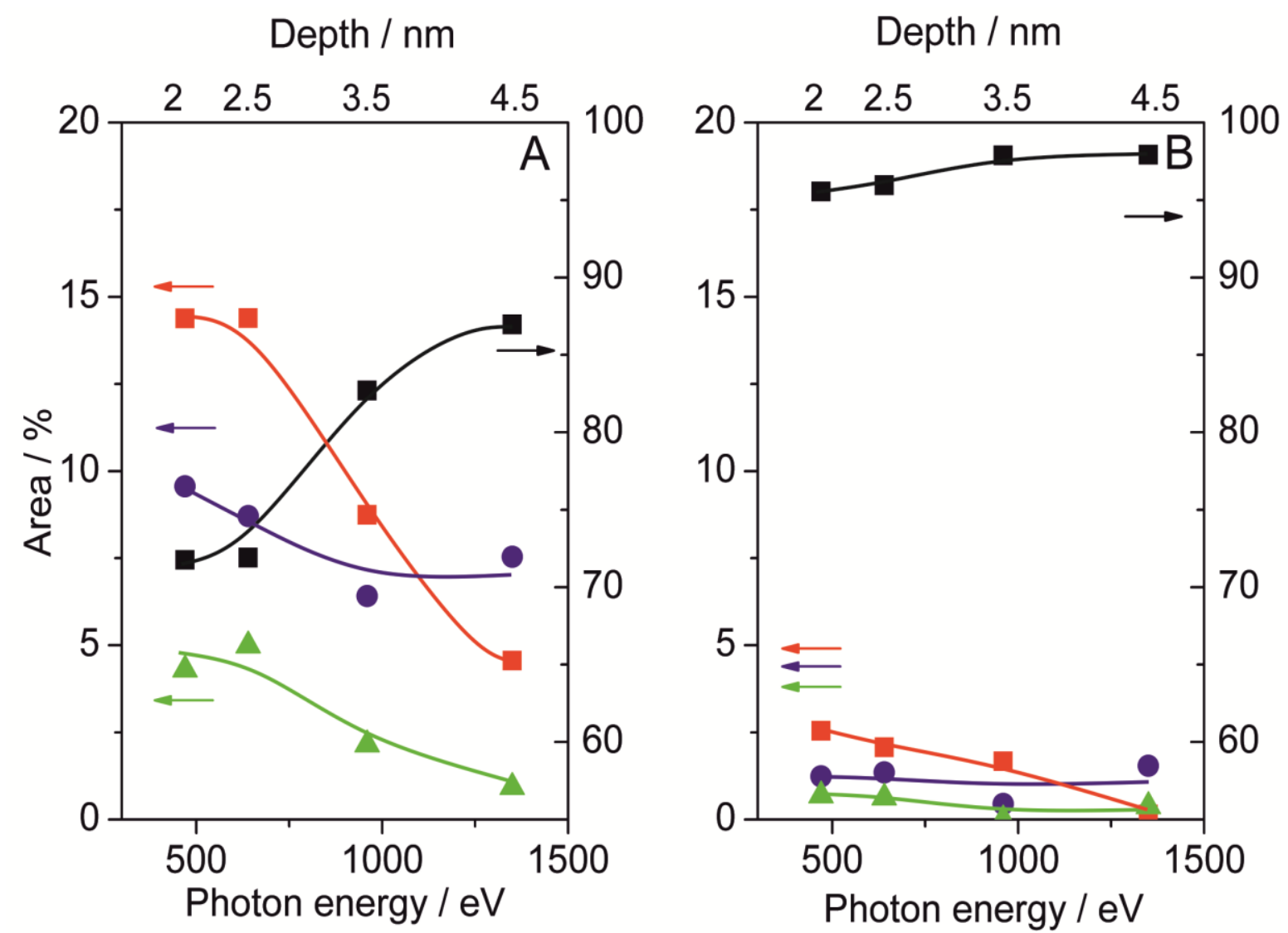

Figure S8: The \% area contribution of $\mathrm{Pt}$ components to the overall $\mathrm{Pt} 4 \mathrm{f}$ spectra, as a function of the photon energy at (A) $0.7 \mathrm{~V}$ (forward scan) and (B) $0.0 \mathrm{~V}$ (backward scan) vs. the $\mathrm{OCV}$ in 0.1 mbar $\mathrm{H}_{2} \mathrm{O}$. Color codes: Pt metal (black); $\mathrm{O} / \mathrm{OH}_{\mathrm{ads}}$ (red); $\mathrm{PtO}$ (blue); $\mathrm{PtO}_{2}$ (green). 
SESSA simulations

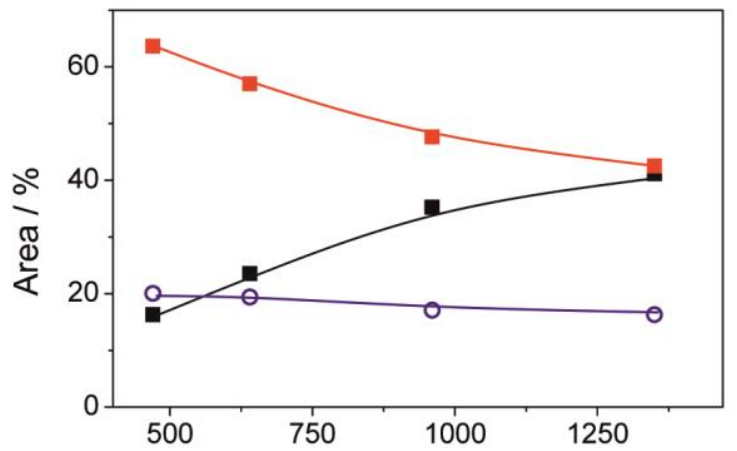

"Planar" morphology

Adsorbate $-0.3 \mathrm{~nm}$

PtO - 0.3nm

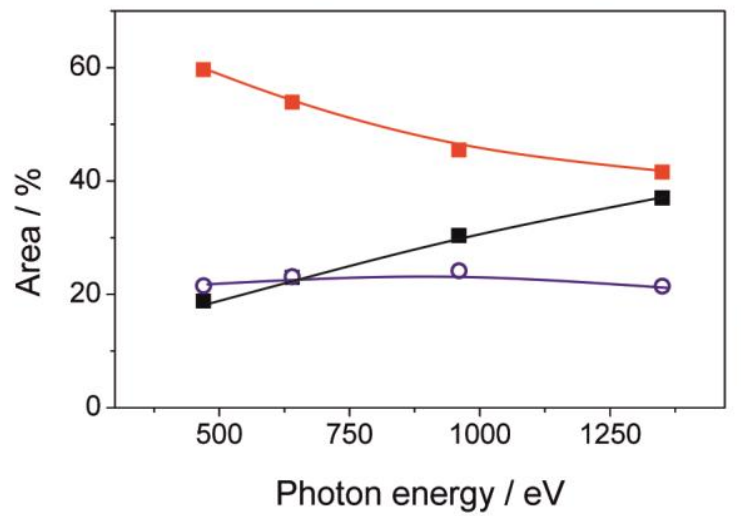

"Layered spheres" morphology

Pt particle - 5nm

Adsorbate - 0.3nm

$\mathrm{PtO}-0.3 \mathrm{~nm}$

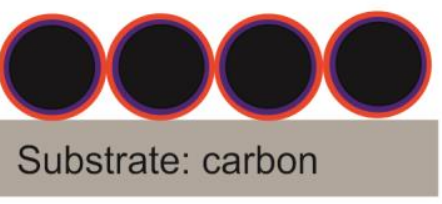

Figure S9: The \% area contribution of $\mathrm{Pt}$ (black), $\mathrm{O}$ adsorbate (red) and PtO (blue) species to the overall Pt4f spectra simulated using "planar" and "layered spheres" morphologies, as a function of the photn energy. Thickness: adsorbate $-0.3 \mathrm{~nm} ; \mathrm{PtO}-$ $0.3 \mathrm{~nm}$. For "layered spheres" morphology the diameter of the particle was assumed as $5 \mathrm{~nm}$ and the material of the substrate was carbon. 


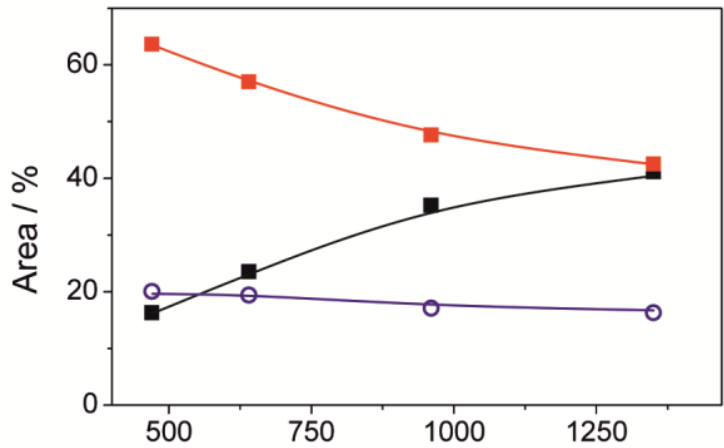

"Planar" morphology

Adsorbate - $0.3 \mathrm{~nm}$

$\mathrm{PtO}-0.3 \mathrm{~nm}$

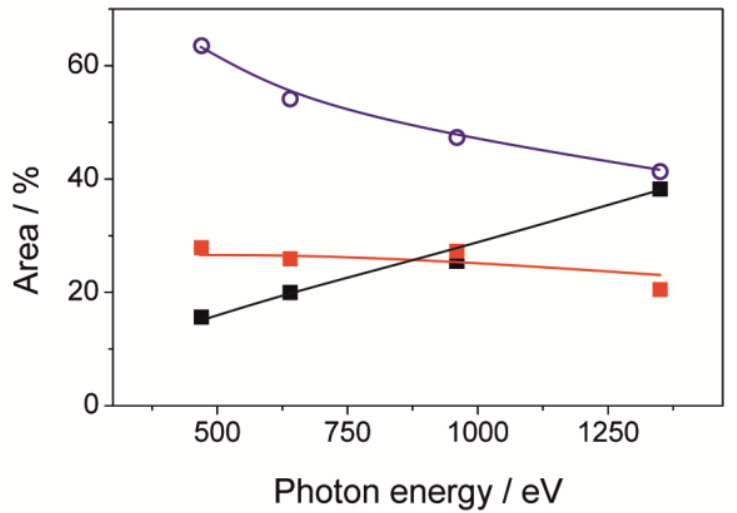

"Islands" morphology

$25 \%$ coverage

Adsorbate - $0.3 \mathrm{~nm}$

PtO - 0.3nm

Figure S10: The \% area contribution of $\mathrm{Pt}$ (black), adsorbate (red) and $\mathrm{PtO}$ (blue) species to the overall Pt4f spectra simulated using "planar" and "islands" morphologies with $25 \%$ coverage, as a function of the photon energy.

Thickness values: adsorbate $-0.3 \mathrm{~nm}$; $\mathrm{PtO}-0.3 \mathrm{~nm}$. 


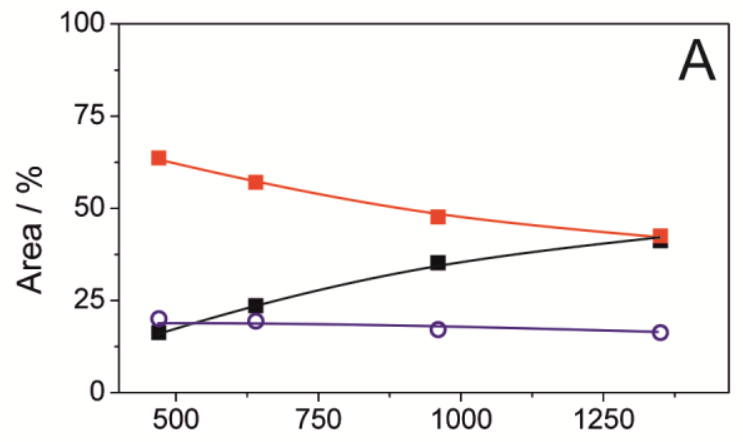

"Planar" morphology

Adsorbate - 0.3nm

$\mathrm{PtO}-0.3 \mathrm{~nm}$

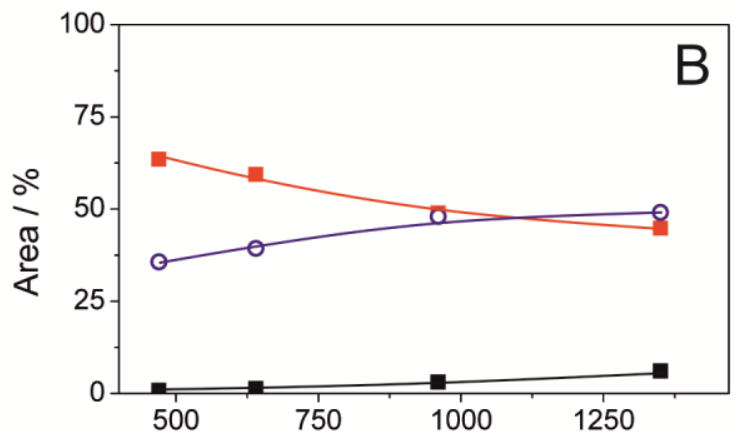

"Planar" morphology

Adsorbate - 0.3nm

$\mathrm{PtO}-2 \mathrm{~nm}$

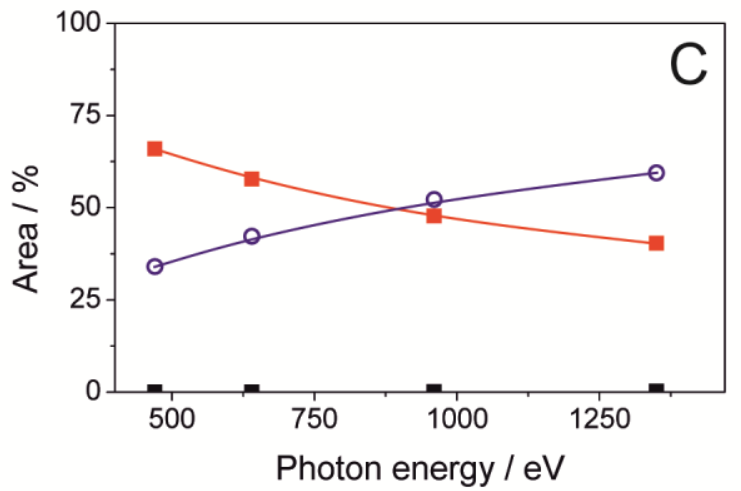

"Planar" morphology

Adsorbate - 0.3nm

$\mathrm{PtO}-6 \mathrm{~nm}$

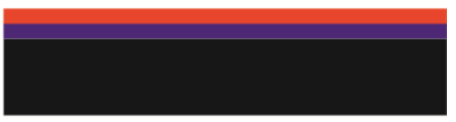

Figure S11: The \% area contribution of $\mathrm{Pt}$ (black), adsorbate (red) and $\mathrm{PtO}$ (blue) species to the overall Pt4f spectra simulated using "planar" morphology, as a function of the photon energy.

Thickness values: adsorbate $-0.3 \mathrm{~nm}$; $\mathrm{PtO}-0.3 \mathrm{~nm}(\mathrm{~A}) ; 2 \mathrm{~nm}(\mathrm{~B}) ; 6 \mathrm{~nm}(\mathrm{C})$. 


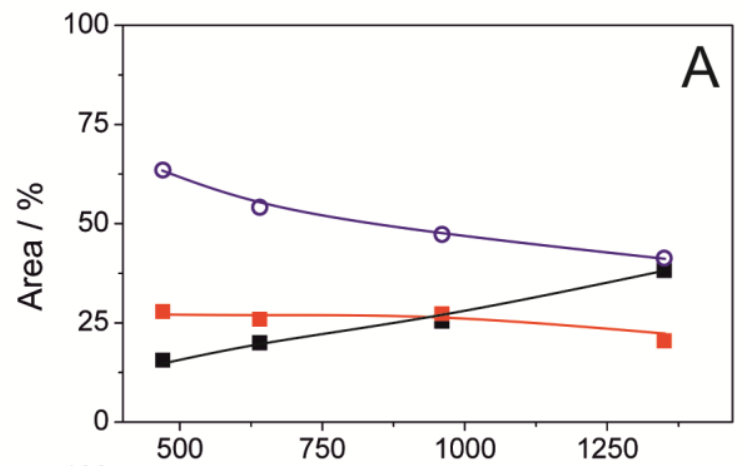

"Islands" morphology $25 \%$ coverage Adsorbate - 0.3nm

PtO - 0.3nm

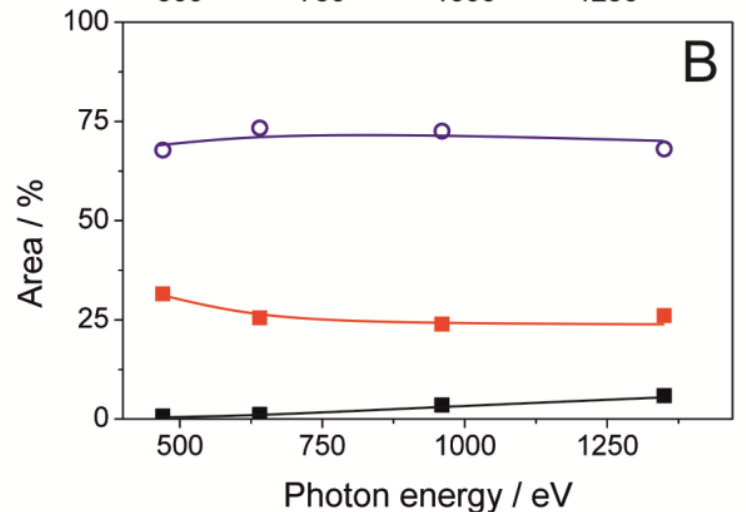

"Islands" morphology $25 \%$ coverage Adsorbate - 0.3nm $\mathrm{PtO}-2 \mathrm{~nm}$

Figure S12: The $\%$ area contribution of $\mathrm{Pt}$ (black), adsorbate (red) and $\mathrm{PtO}$ (blue) species to the overall Pt4f spectra simulated using "islands" morphology with $25 \%$ coverage, as a function of the photon energy.

Thickness values: adsorbate $-0.3 \mathrm{~nm}$; $\mathrm{PtO}-0.3 \mathrm{~nm}(\mathrm{~A}) ; 2 \mathrm{~nm}(\mathrm{~B})$. 


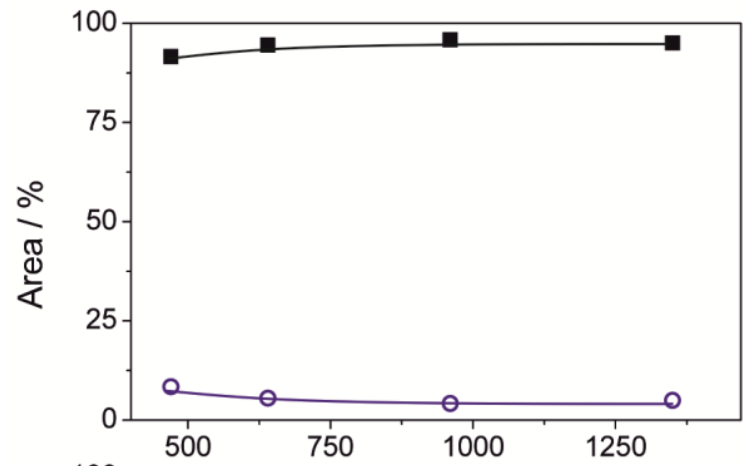

$5 \%$ coverage

PtO - 0.3nm
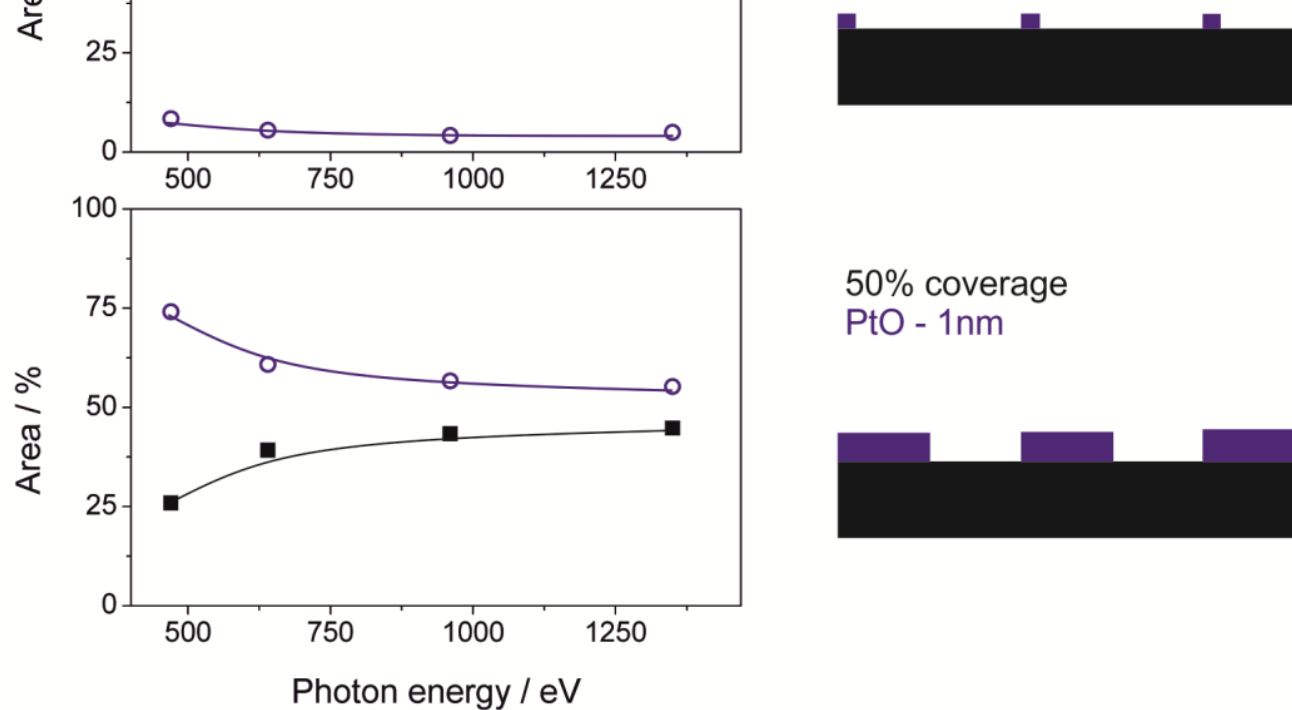

$50 \%$ coverage

$\mathrm{PtO}-1 \mathrm{~nm}$

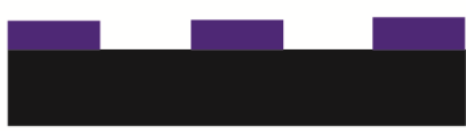

Figure S13: The \% area contribution of Pt (black) and PtO (blue) species to the overall Pt4f spectra simulated using "planar" morphology, as a function of the photon energy at different oxide coverage $-5 \%$ (top) and 50\% (bottom) and different PtO thickness -0.3 $\mathrm{nm}$ (upper) and 1nm (lower). 


\section{REFERENCES}

(1) Papaefthimiou, V.; Diebold, M.; Ulhaq-Bouillet, C.; Doh, W. H.; Blume, R.; Zafeiratos, S.; Savinova, E. R. Potential-Induced Segregation Phenomena in Bimetallic PtAu Nanoparticles: An In Situ Near-Ambient-Pressure Photoelectron Spectroscopy Study. ChemElectroChem 2015, 2 (10), 1519-1526.

(2) Kim, K. S.; Winograd, N.; Davis, R. E. Electron Spectroscopy of Platinum-Oxygen Surfaces and Application to Electrochemical Studies. J. Am. Chem. Soc. 1971, 93 (23), 6296-6297.

(3) Bancroft, M. G.; Adams, I.; Coatsworth, L. L.; Bennewitz, D. C.; Brown, J. D.; Westwood, W. D. ESCA Study of Sputtered Platinum Films. Anal. Chem. 1975, 47 (3), 586-588.

(4) Barr, T. L. An ESCA Study of the Termination of the Passivation of Elemental Metals. $J$. Phys. Chem. 1978, 82 (16), 1801-1810.

(5) Kirner, U. K.; Schierbaum, K. D.; Göpel, W. Interface-Reactions of Pt/Tio2 - Comparative Electrical, Xps-Depth, and Aes-Depth Profile Investigations. Fresenius J. Anal. Chem. 1991, 341 (5-6), 416-420.

(6) Puglia, C.; Nilsson, a.; Hernnäs, B.; Karis, O.; Bennich, P.; Mårtensson, N. Physisorbed, Chemisorbed and Dissociated O2 on Pt(111) Studied by Different Core Level Spectroscopy Methods. Surf. Sci. 1995, 342 (1-3), 119-133.

(7) Kuribayashi, K.; Kitamura, S. Preparation of Pt-PtOx Thin Films as Electrode for Memory Capacitors. Thin Solid Films 2001, 400 (1-2), 160-164.

(8) Parkinson, C. R.; Walker, M.; McConville, C. F. Reaction of Atomic Oxygen with a Pt(llll 111$)$ Surface: Chemical and Structural Determination Using XPS, CAICISS and LEED. Surf. Sci. 2003, 545 (1-2), 19-33.

(9) Chen, Y.-C.; Sun, Y.-M.; Yu, S.-Y.; Hsiung, C.-P.; Gan, J.-Y.; Kou, C.-S. Characterization of Pt Oxide Thin Film Fabricated by Plasma Immersion Ion Implantation. Nucl. Instruments Methods Phys. Res. Sect. B Beam Interact. with Mater. Atoms 2005, 237 (1-2), 296-300.

(10) Blackstock, J. J.; Stewart, D. R.; Li, Z. Plasma-Produced Ultra-Thin Platinum-Oxide Films for Nanoelectronics: Physical Characterization. Appl. Phys. A Mater. Sci. Process. 2005, 80 (6), 1343-1353.

(11) Arrigo, R.; Hävecker, M.; Schuster, M. E.; Ranjan, C.; Stotz, E.; Knop-Gericke, A.; Schlögl, R. In Situ Study of the Gas-Phase Electrolysis of Water on Platinum by NAP-XPS. Angew. Chemie - Int. Ed. 2013, 52 (44), 11660-11664.

(12) Axnanda, S.; Crumlin, E. J.; Mao, B.; Rani, S.; Chang, R.; Karlsson, P. G.; Edwards, M. O. M.; Lundqvist, M.; Moberg, R.; Ross, P.; et al. Using “Tender” X-Ray Ambient Pressure XRay Photoelectron Spectroscopy as A Direct Probe of Solid-Liquid Interface. Sci. Rep. 2015, 5, 9788-9800.

(13) Winograd, N.; Hammond, J. S. XPS Spectroscopic Study of Potentiostatic and Galvanostatic Oxidation of Pt Electrodes in H2SO4 and HClO4. J. Electroanal. Chem. 1977, 78, 55-69.

(14) Sun, A.; Franc, J.; Macdonald, D. D. Growth and Properties of Oxide Films on Platinum. $J$. Electrochem. Soc. 2006, 153 (7), B260-B277. 
(15) Dickinson, T.; Povey, A. F.; Sherwood, P. M. A. X-Ray Photoelectron Spectroscopic Studies of Oxide Films on Platinum and Gold Electrodes. J. Chem. Soc. Faraday Trans. 1 1975, 71, 298-311.

(16) Zhou, Y.; Nakashima, M.; White, J. M. Pt with Ceria and Silica. 1988, 92 (16), 812-818.

(17) Ono, L. K.; Croy, J. R.; Heinrich, H.; Roldan Cuenya, B. Oxygen Chemisorption, Formation, and Thermal Stability of Pt Oxides on Pt Nanoparticles Supported on SiO2/Si(001): Size Effects. J. Phys. Chem. C 2011, 115 (34), 16856-16866.

(18) Fleisch T.H., M. G. J. Photoreduction and Reoxidation of Platinum Oxide and Palladium Oxide Surfaces. J. Phys. Chem 1986, 90, 5317-5320.

(19) Parmigiani, F.; Kay, E.; Bagus, P. S. Anomalous Oxidation of Platinum Clusters Studied by X-Ray Photoelectron-Spectroscopy. J. Electron Spectros. Relat. Phenomena 1990, 50 (1-2), 39-46.

(20) Pitchon, V.; Fritz, A. The Relation between Surface State and Reactivity in the DeNO X Mechanism on Platinum-Based Catalysts. G 1999, 74, 64-74.

(21) Aricò, A. S.; Shukla, A. K.; Kim, H.; Park, S.; Min, M.; Antonucci, V. An XPS Study on Oxidation States of $\mathrm{Pt}$ and Its Alloys with $\mathrm{Co}$ and $\mathrm{Cr}$ and Its Relevance to Electroreduction of Oxygen. Appl. Surf. Sci. 2001, 172 (1-2), 33-40.

(22) Zhao, F.; Ikushima, Y.; Shirai, M.; Ebina, T.; Arai, M. Influence of Electronic State and Dispersion of Platinum Particles on the Conversion and Selectivity of Hydrogenation of an $\alpha, \beta$-Unsaturated Aldehyde in Supercritical Carbon Dioxide. J. Mol. Catal. A Chem. 2002, $180,259-265$.

(23) Sivalingam, G.; Nagaveni, K.; Hegde, M. S.; Madras, G. Photocatalytic Degradation of Various Dyes by Combustion Synthesized Nano Anatase TiO2. Appl. Catal. B Environ. 2003, 45 (1), 23-38.

(24) Després, J.; Elsener, M.; Koebel, M.; Kröcher, O.; Schnyder, B.; Wokaun, A. Catalytic Oxidation of Nitrogen Monoxide over Pt/SiO2. Appl. Catal. B Environ. 2004, 50 (2), 73-82.

(25) Tian, Z. Q.; Jiang, S. P.; Liang, Y. M.; Shen, P. K. Synthesis and Characterization of Platinum Catalysts on Muldwalled Carbon Nanotubes by Intermittent Microwave Irradiation for Fuel Cell Applications. J. Phys. Chem. B 2006, 110 (11), 5343-5350.

(26) Wu, G.; Chen, Y. S.; Xu, B. Q. Remarkable Support Effect of SWNTs in Pt Catalyst for Methanol Electrooxidation. Electrochem. commun. 2005, 7, 1237-1243.

(27) Şen, F.; Gökağaç, G. Different Sized Platinum Nanoparticles Supported on Carbon: An XPS Study on These Methanol Oxidation Catalysts. J. Phys. Chem. C 2007, 111 (15), 5715-5720. 